\title{
ANALISIS EKOLOGI LANSKAP AGROFORESTRI PADA RIPARIAN SUNGAI CILIWUNG DI KOTA BOGOR
}

\section{Analysis Of Agroforestry \\ Landscape Ecology On \\ Ciliwung River Riparian In \\ Bogor City}

\section{Yulius Budi Prastiyo \\ Mahasiswa Departemen \\ Arsitektur Lanskap, \\ Fakultas Pertanian IPB \\ Email: \\ yuliusprastyo93@gmail.com}

\section{Kaswanto \\ Staf Pengajar Departemen \\ Arsitektur Lanskap, \\ Fakultas Pertanian IPB \\ Hadi Susilo Arifin \\ Staf Pengajar Departemen \\ Arsitektur Lanskap, \\ Fakultas Pertanian IPB}

\begin{abstract}
Ciliwung River flows from Bogor District, Bogor City, Depok City, to Jakarta. The river faces many problems, especially settlement occupation on its riparian zones. The problem has damaged its natural ecological structures and the agroforestry practices, such as mixed gardens, forest gardens, and pekarangan (home garden) in riparian landscape. This paper objective is to provide a mapping of the structure, function, and dynamics of riparian agroforestry landscape on Ciliwung River in Bogor City. The landscape ecological index analysis approach is used to quantify the structure, function, and dynamics of the landscape. The existing land use of Ciliwung riparian in Bogor City has been dominated by the built up area, such as settlements and housings. Those land use can be found with an area of $56.54 \%$ in the upper part and $60.50 \%$ in the lower part. Meanwhile, in the middle part of Ciliwung Riparian in Bogor City is still dominated by the agroforestry area, such as forest gardens, mixed garden, and "pekarangan" with an area of 55.23\%. The function of these structures is as the core habitat and movement media of material, energy, animal, and human. Spatial dynamics of the Ciliwung riparian landscape in Bogor City revealed that the more patches of settlements and housing on a landscape, the more patches of pekarangan.
\end{abstract}

Keywords: Ecology, land use, landscape function, landscape dynamic, and landscape structure

\section{PENDAHULUAN}

Okupasi lahan terbangun yang menyebabkan penurunan Ruang Terbuka Hijau (RTH) pada kawasan riparian, telah menjadi isu pokok dalam implementasi tata ruang perkotaan di Indonesia. Berdasarkan UU No. 26 Tahun 2007 tentang Penataan Ruang, disebutkan bahwa dalam rencana penyediaan dan pemanfaatan wilayah kota, RTH publik harus disediakan paling sedikit $20 \%$, sedangkan RTH privat paling sedikit harus $10 \%$ dari luas wilayah kota. Dalam hal jumlah, keduanya harus memiliki total luas lebih besar dari 30\%. Salah satu potensi pengembangan RTH adalah kawasan riparian sungai, karena kawasan tersebut telah dinyatakan sebagai kawasan perlindungan setempat (RI, 1990). Namun pada kenyataannya, beberapa kawasan riparian justru memiliki tingkat okupasi lahan terbangun yang semakin tinggi. Salah satu sungai yang mengalami proses okupasi lahan terbangun pada kawasan ripariannya adalah Sungai Ciliwung, khususnya di Kota Bogor yang merupakan salah satu kota dengan perkembangan yang cukup pesat (Susetyo et al., 2014).

Proses okupasi kawasan lahan terbangun, secara langsung maupun tidak langsung dapat mempengaruhi struktur alami riparian Sungai Ciliwung di Kota Bogor. Struktur alami ekologi lanskap yang sering ditemui pada kawasan riparian sungai, yaitu kebun campuran, talun, dan pekarangan yang merupakan bentuk-bentuk dari praktik agroforestri (Arifin et al., 2009). Perubahanan penggunaan lahan riparian Sungai Ciliwung di Kota Bogor dari kawasan alami menjadi lahan terbangun seperti permukiman dan perumahan, berlangsung sangat cepat. Luasan lahan terbangun bertambah sebesar 14,08 ha dengan laju pertumbuhan sebesar 0,8\% dalam kurun tujuh tahun dari 2006 sampai 2013 (Susetyo et al., 2014). Selain itu, pada tahun 2016, okupasi lahan terbangun pada riparian Sungai Ciliwung bagian hulu mencapai 41,20 ha $(12,46 \%)$, bagian tengah 312,41 ha $(37,11 \%)$, dan bagian hilir mencapai 215,31 ha $(95,72 \%)$ (Noviandi et al. 2016). Kondisi tersebut menunjukkan adanya perubahan lanskap agroforestri pada riparian Sungai Ciliwung di Kota Bogor. Secara ekologis perubahan tersebut telah membentuk karakteristik struktur, fungsi dan dinamika lanskap yang baru.

Usaha dalam menanggulangi permasalahan tersebut harus mulai diproritaskan oleh berbagai pihak terkait. Salah satu cara yang bisa tempuh adalah dengan melakukan restorasi kawasan riparian Sungai Ciliwung di Kota Bogor, melalui manajemen lanskap yang berkelanjutan berdasarkan fungsinya (Noviandi et al., 2016). Namun untuk mendukung usaha tersebut, diperlukan pendekatan-pendekatan baru yang dapat 
memberikan gambaran konfigurasi lanskap secara utuh, salah satunya dengan pendekatan analisis ekologi lanskap (Adi et al., 2012). Analisis ekologi lanskap mencoba untuk mengkuantifikasi proses-proses ekologi dalam suatu lanskap yang berhubungan langsung dengan manusia sebagai pengelola utama lanskap (Leitao \& Ahern, 2002). Analisis tersebut menekankan pada pembahasan mengenai struktur, fungsi, dan dinamika yang terjadi pada lanskap (Arifin et al., 2009). Struktur lanskap dikaitkan dengan ukuran, bentuk, jenis, dan konfigurasi ekosistem elemen penyusun lanskap seperti matriks, patch, dan koridor. Fungsi lanskap mengkaji mengenai aliran energi, materi, dan spesies diantara komponen ekosistem (elemen penyusun lanskap). Dinamika/perubahan lanskap membahas mengenai alterasi struktur dan fungsi lanskap, baik karena gangguan manusia ataupun karena prosesproses alam sendiri. Kemampuan dalam mengukur struktur lanskap akan menjadi dasar dalam pemahanan mengenai fungsi dan dinamika lanskap tersebut (Forman \& Godron, 1983). Oleh karena itu, tulisan ilmiah ini bertujuan untuk menyajikan data struktur, fungsi, dan dinamika lanskap agroforestri riparian Sungai Ciliwung di Kota Bogor secara spasial. Diharapkan hasil informasi spasial tersebut bermanfaat sebagai dasar penyediaan lahan lanskap riparian sungai yang berkelanjutan sesuai fungsinya.

\section{METODOLOGI}

\section{Lokasi dan Waktu Penelitian}

Penelitian dilakukan pada riparian Sungai Ciliwung di Kota Bogor. Riparian Sungai Ciliwung yang diteliti adalah riparian sungai utama sepanjang $14,5 \mathrm{~km}$. Untuk mempermudah analisis dan pengamatan dinamika lanskap secara spasial, lokasi penelitian dibagi menjadi tiga sublokasi yaitu atas, tengah, dan bawah. Pembagian segmen tersebut berdasarkan batas administrasi kelurahan dan kecamatan di Kota Bogor yang dilewati Sungai Ciliwung (Gambar 1 dan Tabel 1). Lebar riparian yang dianalisis ditentukan berdasarkan hasil penelitian analisis lebar riparian ideal Sungai Ciliwung dalam kota dari Noviandi et al. (2016), yaitu $50 \mathrm{~m}$. Penelitian ini dilakukan selama 2 (dua) bulan di lapang, mulai dari bulan Januari sampai dengan Februari 2017.

\section{Alat dan Bahan}

Peralatan yang akan digunakan pada penelitian ini, meliputi kamera digital, seperangkat komputer, pesawat tanpa awak (Unmanned Aerial Vehicle)/drone jenis Quadcopter, Global Positioning System (GPS), serta berbagai software seperti ArcMap 10.4, Erdas Imagine versi 9.1, Fragstats 4.2, Microsoft Word 2013, dan

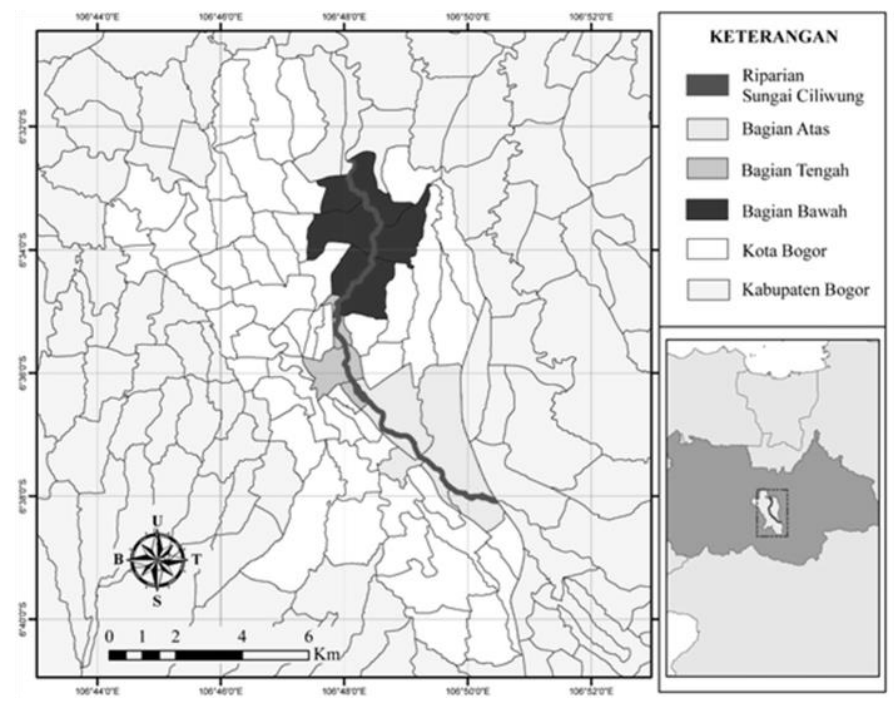

Gambar 1 Lokasi penelitian

Tabel 1 Pembagian segmen penelitian pada lanskap riparian Sungai Ciliwung di Kota Bogor

\begin{tabular}{llll}
\hline No & Kelurahan & Kecamatan & $\begin{array}{l}\text { Bagian } \\
\text { Tapak }\end{array}$ \\
\hline 1 & Katulampa & Bogor Timur & Atas \\
2 & Sindangrasa & Bogor Timur & Atas \\
3 & Tajur & Bogor Timur & Atas \\
4 & Sukasari & Bogor Timur & Atas \\
5 & Baranangsiang & Bogor Timur & Atas \\
6 & Lawanggintung & Bogor Selatan & Atas \\
7 & Babakanpasar & Bogor Tengah & Tengah \\
8 & Paledang (KRB) & Bogor Tengah & Tengah \\
9 & Sempur & Bogor Tengah & Tengah \\
10 & Bantar Jati & Bogor Utara & Bawah \\
11 & Cibuluh & Bogor Utara & Bawah \\
12 & Kedunghalang & Bogor Utara & Bawah \\
13 & Tanah Sareal & Tanah Sareal & Bawah \\
14 & Kedungbadak & Tanah Sareal & Bawah \\
15 & Sukaresmi & Tanah Sareal & Bawah \\
\hline
\end{tabular}


Microsoft Excel 2013. Bahan yang digunakan dalam penelitian ini adalah foto udara dari drone (citra UAV) dan peta penggunaan lahan riparian Sungai Ciliwung di Kota Bogor.

\section{Metode Analisis Data}

Analisis struktur, fungsi, dan dinamika lanskap pada lokasi penelitian dilakukan dengan pendekatan ekologi lanskap. Analisis tersebut merupakan pendekatan baru yang tujuan utamanya untuk menjembatani antara para perencana wilayah dan ahli ekologi, sehingga tercapai pembangunan yang berkelanjutan (Leitao \& Ahern, 2002). Berikut adalah tahapan metode penelitian yang dilakukan.

\section{Pembuatan peta penggunaan lahan (landuse)}

Data spasial yang digunakan adalah citra UAV (Unmanned Aerial Vehicle) dengan resolusi $15 \mathrm{~cm} /$ pixcel. Klasifikasi penggunaan lahan dibagi menjadi sepuluh kelas yaitu sungai utama, talun, kebun campuran, pekarangan, permukiman, perumahan, lahan kosong, kolam, jalan, dan anak sungai. Selanjutnya dilakukan pengambilan titik sesuai dengan intepretasi kondisi penggunaan lahan di lapang (Gambar 2). Proses klasifikasi penggunaan lahan dilakukan mengggunakan perangkat lunak ArcMap 10.4 dengan sistem koordinat yang digunakan dalam koreksi geometrik adalah UTM dengan datum WGS 1984 zona 48S. Intepretasi visual penggunaan lahan dilakukan dengan mendigitasi citra UAV di layar monitor (on-screen digitizing) kedalam bentuk poligon berdasarkan klasifikasi kelas penggunaan lahan. Selanjutnya dilakukan pendugaan akurasi mengguanakan metode akurasi umum (overall accuracy) dan akurasi Kappa (Congalton \& Green, 1999).

\section{Analisis Struktur Lanskap}

Data yang digunakan adalah peta penggunaan lahan (landuse) lokasi penelitian hasil dari analisis tahapan 1. Kelas penggunaan lahan yang digunakan mewakili struktur lanskap berupa jenis-jenis patch dan corridor. Kelas penggunaan lahan sungai utama (SU), tidak dimasukan dalam analisis struktur lanskap, karena merupakan bagian dari badan sungai dan tidak termasuk wilayah riparian. Parameter ekologi lanskap yang dianalisis ada 6 (enam), yang terbagi dalam empat kelompok indeks ekologi lanskap. Keempat kelompok tersebut adalah (1) ukuran-ukuran luas, yaitu Total Class Area (CA) dan Largest Patch Index (LPI), (2) ukuranukuran kerapatan dan variabilitas, yaitu Number of Patch (NP) dan Patch Density (PD), (3) ukuran tepi, yaitu Edge
Density (ED), dan (4) ukuran bentuk, yaitu Landscape Shape Index (LSI). Adapun software yang digunakan untuk menganalisis indeks ekologi tersebut adalah FRAGSTATS 4.2 .

\section{Analisis Fungsi dan Dinamika lanskap}

Analisis fungsi dan dinamika lanskap dilakukan dengan mengkaji hubungan elemen-elemen penyusun lanskap, dalam hal ini adalah patch dan koridor dengan prosesproses alami seperti aliran energi, materi, dan spesies diantara komponen ekosistem (elemen penyusun lanskap). Selanjutnya dikaji juga mengenai perubahan/dinamika struktur dan fungsi lanskap tersebut seiring dengan perubahan secara spasial.

\section{HASIL DAN PEMBAHASAN Analisis Situasional Lokasi Penelitian}

Sungai Ciliwung memiliki hulu di Kabupaten Bogor, mengalir melalui beberapa wilayah yakni Kabupaten Bogor, Kota Bogor, Depok, dan Jakarta, hingga akhirnya bermuara di Teluk Jakarta. Sungai ini memiliki panjang kurang lebih $117 \mathrm{~km}$ dengan kedalaman rata-rata kurang dari $4 \mathrm{~m}$ dan kecepatan aliran air mencapai $5 \mathrm{~m} /$ det. Dalam skala DAS, curah hujan rata-rata di wilayah Sungai Ciliwung sebesar $2.913 \mathrm{~mm} /$ tahun dan termasuk kategori tinggi. Berdasarkan klasifikasi Schmidth dan Ferguson, tipe iklim di DAS Ciliwung adalah tipe iklim A yang memiliki Bulan Basah $(\mathrm{CH}>100 \mathrm{~mm} /$ bulan $) 10$ bulan, Bulan Lembab 2 bulan ( $\mathrm{CH} 60-100 \mathrm{~mm} /$ bulan), dan tidak memiliki bulan kering. Jenis tanah yang paling banyak terdapat di DAS Ciliwung adalah jenis asosiasi latosol merah, latosol coklat kemerahan, dan laterit air tanah (BPDASCC, 2013). Sungai Ciliwung yang melintasi Kota Bogor termasuk kedalam sub DAS Ciliwung bagian Tengah. Panjang Sungai Ciliwung yang melintasi Kota Bogor mencapai 14,46 km yang termasuk kedalam wilayah administrasi 15 kelurahan (Tabel 1). Luas kawasan riparian Sungai Ciliwung di Kota Bogor bila menggunakan standar lebar riparian $50 \mathrm{~m}$ (Noviandi et al., 2016) mencapai 148,97 ha. Topografi daerah ini bergelombang dan berbukit-bukit dengan variasi kemiringan $2-15 \%$ dan memiliki ketinggian $120-$ $350 \mathrm{~m} \mathrm{dpl}$.

\section{Analisis Penggunaan Lahan}

Klasifikasi penggunaan lahan yang diintepratasi dari citra UAV dalam penelitian ini, dibagi menjadi 10 kelas yaitu, Sungai Utama (SU), Talun (TL), Kebun Campuran (KC), Pekarangan (PK), Permukiman (PM), Perumahan (PR), Lahan Kosong (LK), Kolam (KL), Jalan (JL), dan Anak Sungai (AS). Peta penggunaan lahan riparian Sungai Ciliwung di Kota Bogor yang telah dibuat, 


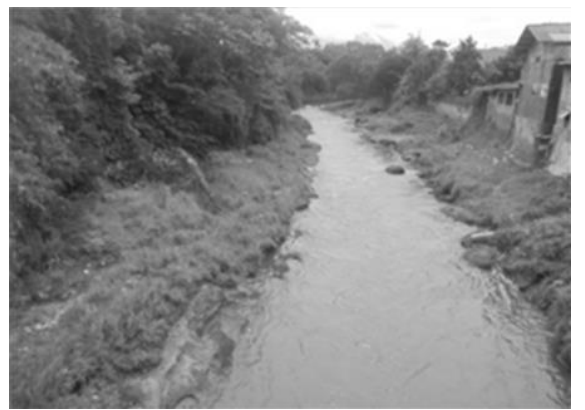

(a) Sungai utama

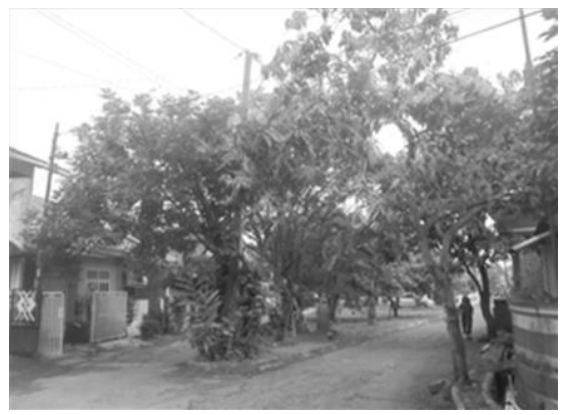

(d) Pekarangan

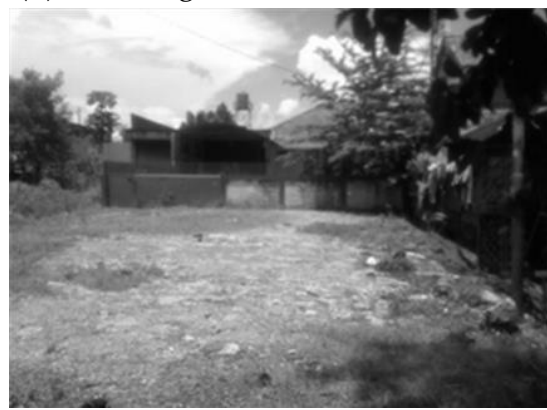

(g) Lahan kosong

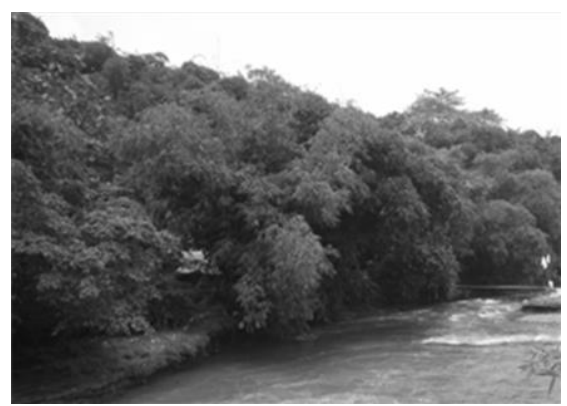

(b) Talun

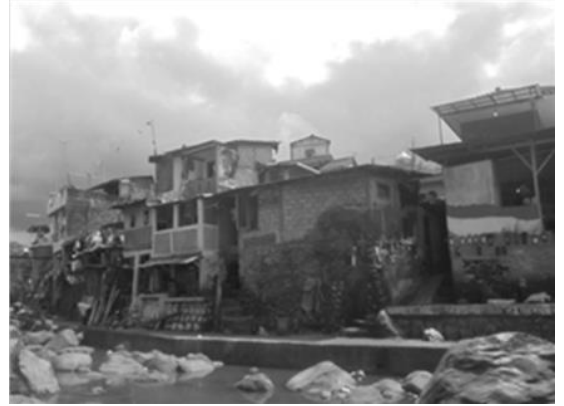

(e) Permukiman

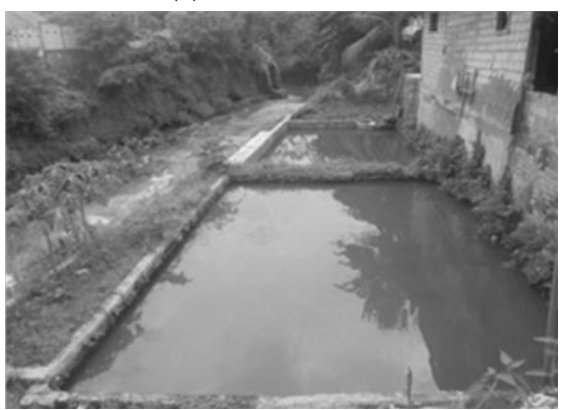

(h) Kolam

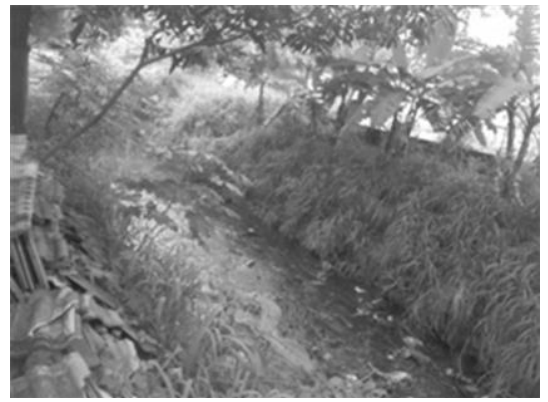

(j) Anak sungai

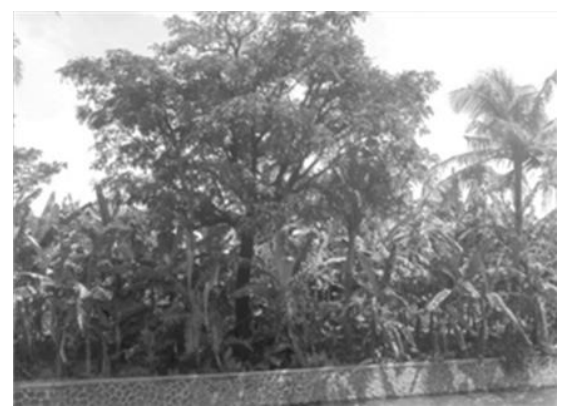

(c) Kebun campuran

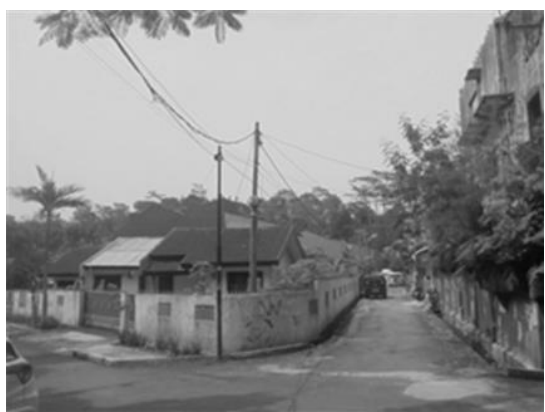

(f) Perumahan

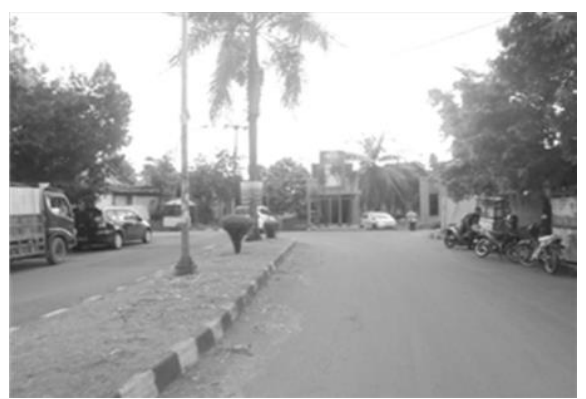

(i) Jalan

Gambar 2 Contoh penggunaan lahan riparian Sungai Ciliwung di Kota Bogor.

selanjutnya dievaluasi menggunakan teknik akurasi. Teknik akurasi klasifikasi penggunaan lahan dilakukan dengan metode akurasi umum (overall accuracy) dan akurasi Kappa (Congalton \& Green, 1999). Nilai akurasi umum klasifikasi penggunaan lahan riparian Sungai Ciliwung di Kota Bogor mencapai 87,21 \%, sedangkan untuk akurasi kappa diperoleh akurasi sebesar 81,44\%. Nilai akurasi tersebut tegolong tinggi, yang menunjukkan jika peta penggunaan lahan tersebut akurat dan sesuai kondisi sebenarnya di lapangan (Khoiriah \& Farda, 2010).

Luas riparian Sungai Ciliwung di Kota Bogor (lebar riparian $50 \mathrm{~m}$ ) pada segmen atas mencapai 55,83 ha, segmen tengah mencapai 31,85 ha, dan segmen bawah mencapai 61,29 ha. Penggunaan lahan eksisting pada riparian Sungai Ciliwung di Kota Bogor segmen atas 
didominasi oleh penggunaan lahan berupa perumahan dengan luas 11,52 ha atau $20,63 \%$, dan kemudian disusul oleh penggunaan lahan permukiman dengan luas 10,82 ha atau $19,38 \%$. Segmen tengah didominasi oleh penggunaan lahan berupa talun dengan luas 14,97 ha atau $47,00 \%$, dan diikuti oleh penggunaan lahan permukiman dengan luas 8,51 ha atau $26,73 \%$. Segmen bawah didominasi oleh penggunaan lahan permukiman dengan luas 19,38 ha atau 31,61\%, kemudian disusul penggunaan lahan talun dengan luas 13,26 ha atau $21,64 \%$ (Tabel 2).

\section{Analisis Struktur Ekologi Lanskap}

Kelas penggunaan lahan yang digunakan mewakili struktur ekologi lanskap yang dianalisis yaitu berupa jenis-jenis patch dan corridor, dan matrix. Patch adalah area permukaan non linier yang berbeda penampakannya dari area sekitarnya dan merupakan unit dasar dari suatu lanskap. Koridor (corridor) adalah area permukaan homogen yang bentuknya memanjang dan berkesinambungan (connectivity). Matrik (matrix) adalah area permukaan yang paling dominan dari mosaik lanskap yang akhirnya menjadi tipe elemen lanskap dan memainkan peran fungsi yang dominan dalam lanskap tersebut (Forman \& Godron, 1986 dan Arifin et al., 2009). Elemen struktur lanskap tersebut akan dikuantifikasikan dengan menggunakan parameter

Tabel 2 Hasil analisis indeks ukuran-ukuran luas struktur ekologi lanskap

\begin{tabular}{|c|c|c|c|c|c|c|c|c|c|c|}
\hline \multirow{4}{*}{ No } & \multirow{4}{*}{$\begin{array}{c}\text { Kelas } \\
\text { Penggunaan } \\
\text { Lahan }\end{array}$} & \multicolumn{9}{|c|}{ Nilai Indeks Ekologi } \\
\hline & & \multicolumn{6}{|c|}{ Total (Class) Area (CA) (ha) } & \multicolumn{3}{|c|}{ Largest Patch Index (LPI) } \\
\hline & & \multicolumn{2}{|c|}{ Atas } & \multicolumn{2}{|c|}{ Tengah } & \multicolumn{2}{|c|}{ Bawah } & \multirow{2}{*}{ Atas } & \multirow{2}{*}{ Tengah } & \multirow{2}{*}{ Bawah } \\
\hline & & ha & $\%$ & ha & $\%$ & ha & $\%$ & & & \\
\hline 1 & Talun & 13.26 & 21.64 & 14.97 & 47.00 & 10.54 & 18.88 & 4.08 & 18.78 & 3.25 \\
\hline 2 & $\begin{array}{c}\text { Kebun } \\
\text { Campuran }\end{array}$ & 5.00 & 8.15 & 0.09 & 0.29 & 4.35 & 7.80 & 1.80 & 0.29 & 1.08 \\
\hline 3 & Pekarangan & 7.94 & 12.95 & 2.53 & 7.93 & 7.06 & 12.65 & 0.72 & 2.03 & 0.29 \\
\hline 4 & Permukiman & 19.38 & 31.61 & 8.51 & 26.73 & 10.82 & 19.38 & 2.67 & 1.87 & 0.71 \\
\hline 5 & Perumahan & 6.71 & 10.95 & 2.44 & 7.67 & 11.52 & 20.63 & 0.55 & 1.08 & 1.21 \\
\hline 6 & Lahan Kosong & 3.13 & 5.11 & 0.96 & 3.01 & 4.52 & 8.09 & 0.37 & 0.76 & 0.76 \\
\hline 7 & Kolam & 0.62 & 1.02 & 0.16 & 0.49 & 0.61 & 1.09 & 0.35 & 0.32 & 0.07 \\
\hline 8 & Jalan & 4.81 & 7.86 & 2.19 & 6.87 & 6.31 & 11.31 & 1.46 & 1.16 & 1.53 \\
\hline 9 & Anak Sungai & 0.44 & 0.71 & 0.00 & 0.00 & 0.09 & 0.17 & 0.18 & 0.00 & 0.05 \\
\hline & Total & 61.29 & 100.00 & 31.85 & 100.00 & 55.83 & 100.00 & & & \\
\hline
\end{tabular}

Tabel 3 Hasil analisis indeks ukuran-ukuran kerapatan dan variabilitas struktur ekologi lanskap

\begin{tabular}{|c|c|c|c|c|c|c|c|}
\hline \multirow{3}{*}{ No } & \multirow{3}{*}{ Kelas Penggunaan Lahan } & \multicolumn{6}{|c|}{ Nilai Indeks Ekologi } \\
\hline & & \multicolumn{3}{|c|}{ Number of Patches (NP) } & \multicolumn{3}{|c|}{ Patch Density (PD) } \\
\hline & & Atas & Tengah & Bawah & Atas & Tengah & Bawah \\
\hline 1 & Talun & 31.00 & 25.00 & 37.00 & 50.58 & 78.50 & 66.27 \\
\hline 2 & Kebun Campuran & 22.00 & 1.00 & 29.00 & 35.89 & 3.14 & 51.95 \\
\hline 3 & Pekarangan & 546.00 & 130.00 & 788.00 & 890.80 & 408.19 & 1411.47 \\
\hline 4 & Permukiman & 171.00 & 84.00 & 212.00 & 278.99 & 263.76 & 379.74 \\
\hline 5 & Perumahan & 102.00 & 23.00 & 134.00 & 166.41 & 72.22 & 240.02 \\
\hline 6 & Lahan Kosong & 80.00 & 22.00 & 115.00 & 130.52 & 69.08 & 205.99 \\
\hline 7 & Kolam & 32.00 & 2.00 & 61.00 & 52.21 & 6.28 & 109.26 \\
\hline 8 & Jalan & 69.00 & 25.00 & 59.00 & 112.57 & 78.50 & 105.68 \\
\hline 9 & Anak Sungai & 9.00 & 0.00 & 9.00 & 14.68 & 0.00 & 16.12 \\
\hline
\end{tabular}


ekologi lanskap. Parameter ekologi lanskap yang dianalisis ada 6 (enam), yang terbagi dalam empat kelompok indeks ekologi lanskap. Keempat kelompok tersebut adalah (1) ukuran-ukuran luas, yaitu Total Class Area (CA) dan Largest Patch Index (LPI), (2) ukuranukuran kerapatan dan variabilitas, yaitu Number of Patch (NP) dan Patch Density (PD), (3) ukuran tepi, yaitu Edge Density (ED), dan (4) ukuran bentuk, yaitu Landscape Shape Index (LSI). Berikut adalah hasil dan pembahasan dari analisis struktur lanskap riparian Sungai Ciliwung di Kota Bogor.

\section{Bagian Atas}

Bagian atas merupakan bagian riparian Sungai Ciliwung di Kota Bogor yang masuk pada wilayah kelurahankelurahan di Kecamatan Bogor Selatan dan Bogor Timur (Tabel 1). Bagian ini berada pada bagian hilir dari tapak, termasuk kawasan pinggiran kota bagian selatan yang cukup jauh dari pusat Kota Bogor (Gambar 3). Berdasarkan hasil analisis ukuran luas lanskap (CA dan LPI), didapatkan nilai indeks CA pada bagian atas paling besar adalah patch permukiman dengan luas 19,38 ha $(31,61 \%)$, kemudian disusul talun dan pekarangan dengan luas masing-masing 13,26 ha $(21,64 \%)$ dan 7,94 ha $(12,95 \%)$. Sedangkan nilai LPI tertinggi pada bagian atas adalah jenis patch talun dengan nilai 4,08 disusul patch permukiman dengan nilai 2,67 diposisi kedua dan kebun campuran 1,80 diposisi ketiga (Tabel 2). Data tersebut menunjukkan bahwa struktur lanskap riparian Sungai Ciliwung di Kota Bogor bagian atas memiliki matrik berupa lanskap permukiman. Dominansi patch permukiman mengindikasikan adanya intervensi aktivitas manusia yang tinggi pada lanskap tersebut.
Ukuran kerapatan struktur ekologi lanskap riparian Sungai Ciliwung di Kota Bogor pada bagian atas dapat dilihat berdasarkan nilai indeks NP dan PD. Jumlah patch (NP) terbanyak pada bagian ini adalah pekarangan dengan 546 patches, diikuti permukiman dan perumahan dengan jumlah masing-masing sebanyak 171 dan 102 patches. Seperti halnya indeks NP, nilai PD tertinggi pada bagian atas adalah pekarangan dengan 891 patches/100 ha, diikuti patch permukiman dan perumahan dengan jumlah masing-masing sebanyak 279 dan 166 patches/100 ha (Tabel 3). Data tersebut menunjukkan bahwa ketiga jenis patch tersebut telah mengalami pemecahan lahan menjadi beberapa bagian yang membentuk poligon baru dan menyebar (fragmentasi lahan). Dalam hal ini, hadirnya patch permukiman dan perumahan sebagai bentuk intervensi manusia, telah memecah-mecah patch pekarangan yang merupakan salah satu struktur lanskap agroforestri riparian sungai menjadi berukuran kecil dan menyebar. Hal tersebut diperkuat oleh penyataan Hartvigsen (2014), di mana fragmentasi lahan menyebabkan terbaginya lahan (patch) menjadi unit-unit yang berukuran lebih kecil akibat eksploitasi oleh manusia.

Nilai ED tertinggi pada lanskap riparian Sungai Ciliwung di Kota Bogor pada bagian atas adalah patch pekarangan dengan nilai 635,98 (Tabel 4). Nilai indeks ini akan berhubungan dengan nilai NP dan CA yang menunjukkan bahwa patch pekarangan memiliki bentuk tepi yang tidak teratur (McGarigal \& Marks, 1995). Nilai LSI tertinggi pada bagian ini adalah koridor jalan dengan nilai 41,18 dan disusul patch pekarangan dengan nilai sebesar 37,47; 24,02; dan 21,68 (Tabel 4). Indeks ini, menunjukkan bahwa koridor jalan dan patch permukiman merupakan struktur buatan yang kompeks

Tabel 4. Hasil analisis indeks ukuran-ukuran tepi dan bentuk struktur ekologi lanskap

\begin{tabular}{lccccccc}
\hline \multirow{2}{*}{ No } & Kelas Penggunaan & \multicolumn{6}{c}{ Nilai Indeks Ekologi } \\
\cline { 3 - 7 } & Lahan & \multicolumn{3}{c}{ Edge Density (ED) } & \multicolumn{4}{c}{ Landscape Shape Index (LSI) } \\
\cline { 3 - 7 } & & Atas & Tengah & Bawah & Atas & Tengah & Bawah \\
\hline 1 & Talun & 274.55 & 178.35 & 262.82 & 21.68 & 9.75 & 21.18 \\
2 & Kebun Campuran & 82.45 & 4.35 & 107.79 & 7.57 & 1.73 & 9.22 \\
3 & Pekarangan & 635.98 & 276.93 & 768.15 & 37.47 & 15.93 & 43.99 \\
4 & Permukiman & 560.25 & 392.70 & 471.11 & 24.02 & 14.85 & 23.48 \\
5 & Perumahan & 242.24 & 125.32 & 385.75 & 17.81 & 8.20 & 18.85 \\
6 & Lahan Kosong & 126.71 & 64.62 & 184.03 & 12.71 & 6.08 & 14.21 \\
7 & Kolam & 31.13 & 11.43 & 53.71 & 6.50 & 2.87 & 10.21 \\
8 & Jalan & 538.98 & 455.75 & 601.12 & 41.18 & 27.30 & 36.03 \\
9 & Anak Sungai & 48.90 & 0.00 & 12.69 & 12.32 & 0.00 & 6.47 \\
\hline
\end{tabular}


sebagai habitat inti (core) dan media pergerakan manusia, sedangkan patch pekarangan dan talun merupakan struktur alami riparian sungai bagian atas yang paling komplek dan beragam (Adi et al., 2012).

\section{Bagian Tengah}

Segmen tengah merupakan bagian riparian Sungai Bagian tengah merupakan bagian riparian Sungai Ciliwung di Kota Bogor yang masuk pada wilayah kelurahan-kelurahan di Kecamatan Bogor Tengah (Tabel 1). Bagian tengah termasuk kawasan pusat pemerintahan dan pusat ekonomi Kota Bogor, namun pada bagian ini terdapat kawasan lindung (konservasi) yaitu Kebun Raya Bogor (Gambar 4). Berdasarkan hasil analisis ukuran luas lanskap (CA dan LPI), didapatkan nilai indeks CA pada bagian tengah paling besar adalah patch talun dengan luas 14,97 ha $(47,00 \%)$, kemudian

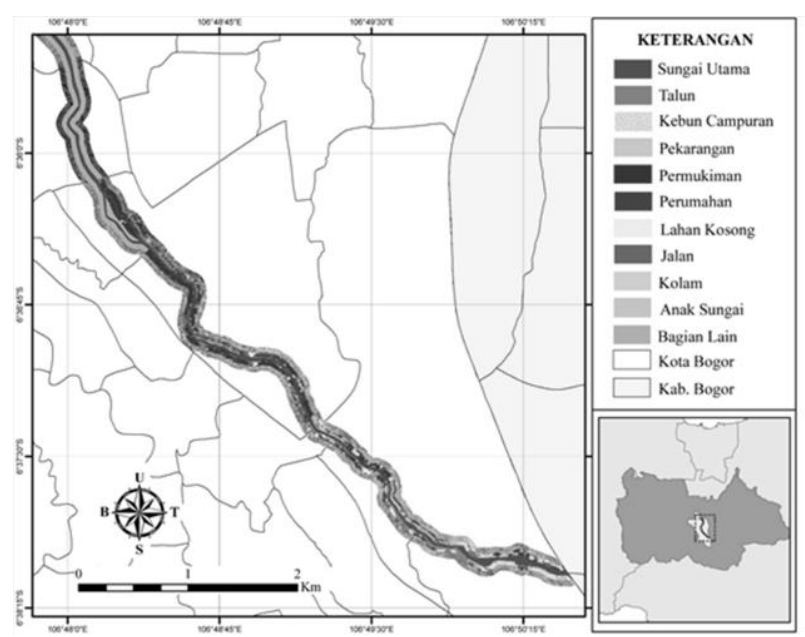

Gambar 3 Peta penggunaan lahan riparian Sungai Ciliwung di Kota Bogor bagian atas

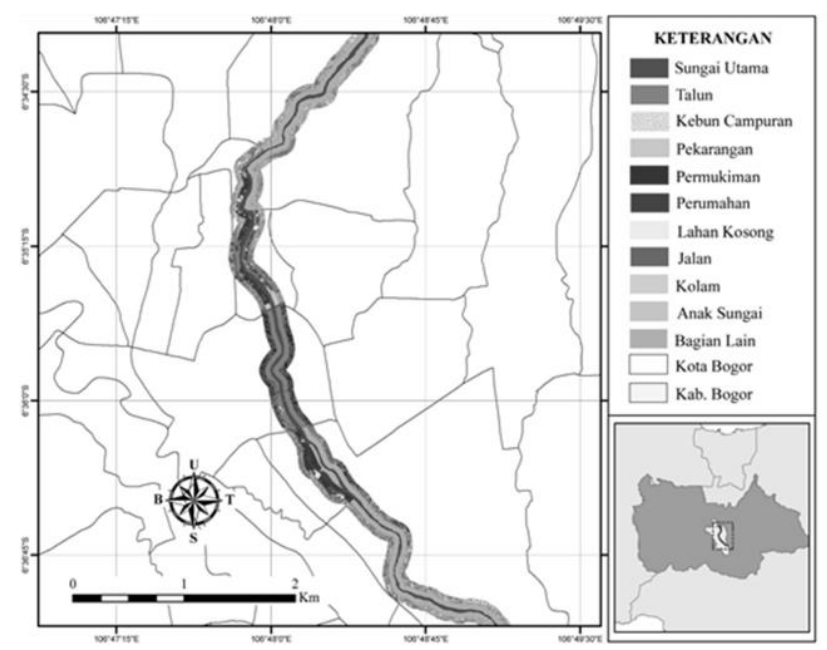

Gambar 4 Peta penggunaan lahan riparian Sungai Ciliwung di Kota Bogor bagian tengah disusul patch permukiman dan pekarangan dengan luas masing-masing sebesar 8,51 ha $(26,73 \%)$ dan 2,53 ha $(7,93 \%)$. Sedangkan nilai LPI tertinggi pada bagian tengah adalah patch talun dengan nilai 18,78 kemudian diikuti patch pekarangan dan permukiman dengan nilai LPI masing-masing sebesar 2,03 dan 1,87 (Tabel 2). Data tersebut menunjukkan bahwa struktur lanskap riparian Sungai Ciliwung di Kota Bogor bagian tengah memiliki matrik lanskap berupa talun. Hal tersebut disebabkan karena pada bagian tengah, terdapat Kebun Raya Bogor yang merupakan kawasan konservasi ex-situ yang tidak boleh dialihfungsikan (RI, 2011).

Jumlah patch (NP) terbanyak pada bagian tengah adalah pekarangan dengan jumlah 130 patches, diikuti patch permukiman ditempat kedua dengan jumlah 84 patches. Seperti halnya indeks NP, nilai PD tertinggi pada bagian tengah adalah pekarangan dengan jumlah 408 patches/100 ha, diikuti patch permukiman ditempat kedua dengan jumlah 264 patches/100 ha (Tabel 3). Data tersebut menunjukkan bahwa kedua jenis patch tersebut mengalami fragmentasi lahan. Hadirnya patch permukiman telah memecah-mecah patch pekarangan yang merupakan salah satu struktur lanskap agroforestri riparian sungai menjadi berukuran kecil dan menyebar. Nilai LSI tertinggi pada bagian tengah adalah koridor jalan dengan nilai 27,30 dan disusul patch permukiman, talun, dan pekarangan dengan nilai masing-masing sebesar 15,93; 14,85; dan 9,75 (Tabel 4). Nilai indeks tersebut menunjukkan bahwa koridor jalan dan patch permukiman (struktur buatan) dan patch pekarangan dan talun (struktur agroforestri) memiliki bentuk yang kompeks dan beragam.

\subsubsection{Bagian Bawah}

Bagian bawah merupakan bagian riparian Sungai Ciliwung di Kota Bogor bagian hilir yang masuk pada wilayah kelurahan-kelurahan di Kecamatan Bogor Utara dan Tanah Sareal (Tabel 1). Bagian ini termasuk kawasan pingiran Kota Bogor bagian utara, namun padat penduduk (Gambar 5). Berdasarkan hasil analisis ukuran luas lanskap (CA dan LPI), didapatkan nilai indeks CA terbesar adalah patch perumahan dengan luas 11,52 ha $(20,63 \%)$ dan disusul patch permukiman, talun, dan pekarangan dengan luas masing-masing sebesar 10,82 ha $(19,38 \%), 10,54$ ha $(18,88 \%)$, dan 7,06 ha $(12,65 \%)$. Sedangkan tiga nilai LPI tertinggi pada bagian bawah adalah patch talun, jalan, perumahan dengan nilai masing-masing adalah 3,25; 1,53; dan 1,21 (Tabel 2). Data tersebut menunjukkan bahwa struktur lanskap riparian Sungai Ciliwung di Kota Bogor bagian bawah memiliki matrik lanskap berupa perumahan. Dominansi patch perumahan pada bagian ini mengindikasikan adanya 
intervensi aktivitas manusia yang tinggi yang mengambil alih kawasan alami riparian sungai.

Ukuran kerapatan struktur ekologi lanskap riparian Sungai Ciliwung di Kota Bogor pada bagian bawah dapat dilihat berdasarkan nilai indeks NP dan PD. Jumlah patch (NP) terbanyak adalah pekarangan dengan jumlah 788 patches, diikuti patch permukiman dan perumahan dengan jumlah masing-masing sebanyak 212 dan 134 patches. Seperti halnya indeks NP, nilai PD tertinggi pada bagian bawah adalah pekarangan dengan jumlah 411 patches/100 ha, diikuti patch permukiman dan perumahan dengan jumlah masing-masing sebanyak 378 dan 240 patches/100 ha (Tabel 3). Data tersebut menunjukkan bahwa ketiga jenis patch tersebut telah terpecah-pecah membentuk poligon-poligon baru yang lebih kecil dan menyebar (fragmentasi lahan). Dalam hal ini, terfragmentasinya patch pekarangan yang merupakan salah satu struktur agroforestri riparian sungai diakibatkan oleh pembangunan perumahan/permukiman yang dapat meningkatkan fragmentasi lahan (York, 2011).

Nilai ED tertinggi pada bagian bawah adalah adalah patch pekarangan dengan nilai 768,15 dan disusul koridor jalan, patch permukiman, dan talun dengan nilai masing-masing sebesar 601,12; 471,11; dan 262,82. Sedangkan nilai LSI tertinggi pada bagian ini adalah patch pekarangan dengan nilai 43,99 dan disusul koridor jalan, patch permukiman, dan talun dengan nilai masingmasing sebesar 36,03; 23,48; dan 21,18 (Tabel 4). Nilai indeks-indeks tersebut menunjukkan bahwa patch pekarangan memiliki bentuk tepi yang paling tidak teratur dan kompleks (McGarigal \& Marks, 1995).

\section{Analisis Fungsi dan Dinamika Lanskap}

Selain struktur lanskap, kajian ekologi lanskap juga menitikberatkan pembahasan mengenai fungsi dan dinamika/perubahan lanskap. Fungsi lanskap mengkaji mengenai interaksi diantara elemen spasial lanskap, seperti aliran energi, materi, dan spesies. Dinamika/perubahan lanskap membahas mengenai perubahan struktur dan fungsi dari mosaik ekologi lanskap seiring dengan perubahan secara spasial maupun temporal, baik karena disebabkan oleh gangguan manusia ataupun karena alam (Forman \& Godron, 1983). Berikut adalah hasil analisis fungsi dan dinamika lanskap riparian Sungai Ciliwung di Kota Bogor.

\section{Analisis Fungsi Lanskap}

Dari uraian tersebut, diketahui bahwa salah satu fungsi lanskap secara ekologis adalah dapat mengaliran enegi,

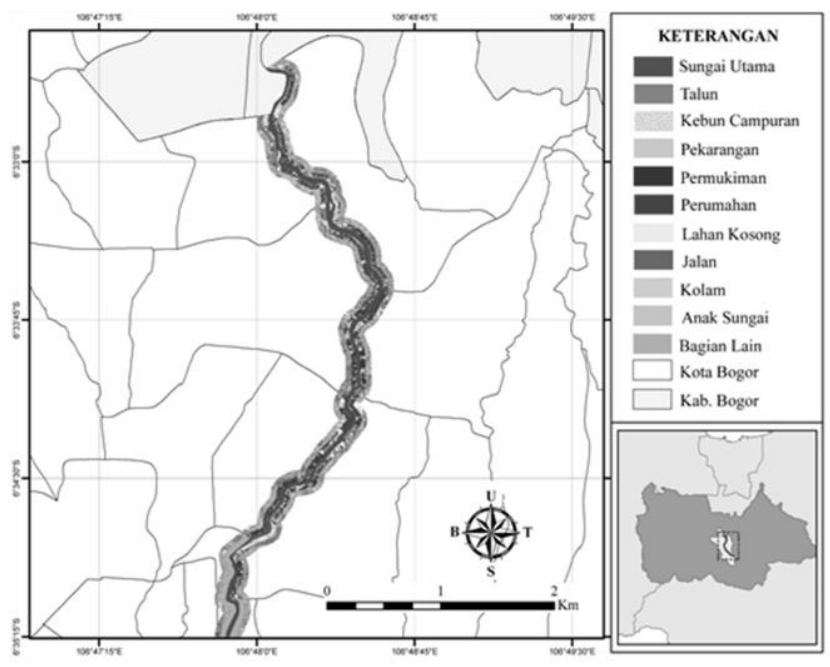

Gambar 5 Peta penggunaan lahan riparian Sungai Ciliwung di Kota Bogor bagian bawah

material, dan spesies diantara elemen penyusunnya. Bagian tepi (edge) elemen lanskap seperti patch dan koridor berfungsi sebagai penyaring arus/aliran yang masuk dan keluar dari elemen tersebut. Aliran-aliran yang masuk kedalam suatu lanskap biasanya akan melewati vegetasi tepi yang padat, atau hanya mengalir sepanjang tepi elemen tersebut. Elemen lanskap yang berdekatan memiliki tingkat kematangan lanskap yang berbeda sehingga fungsi dari kedua elemen tersebut juga berbeda, misalnya elemen dengan tingkat yang matang bisanya berfungsi sebagai tempat sumber makanan dan yang lebih muda sebagai tempat bersarangnya satwa tertentu. Aliran-aliran yang terjadi erat kaitnya dengan pergerakan material, energi dan spesies yang dapat terjadi udara, darat, air, maupun di dalam tanah. Energi, nutrisi/hara, sedimentasi, dan sebagian besar spesies berpindah dari satu elemen yang satu ke elemen lain dalam suatu lanskap. Hal tersebut juga dilakukan oleh hewan-hewan dengan habitat di dalam tanah dan juga lewat berbagai aktivitas manusia (Forman \& Godron, 1983).

Lanskap riparian Sungai Ciliwung di Kota Bogor memiliki struktur lanskap berupa patch, koridor, dan matrik pada setiap bagian. Struktur lanskap tersebut diidentifikasi menjadi kelas/jenis-jenis penggunaan lahan. Lanskap riparian sungai seharusnya memiliki struktur berupa kawasan alami yang berfungsi sebagai kawasan penyangga sungai (Dindaroglu et al., 2015). Selain koridor anak sungai, terdapat struktur lanskap agroforestri yang ditemukan pada riparian Sungai Ciliwung di Kota Bogor yaitu pacth-patch berupa talun, kebun campuran, dan pekarangan (Gambar 3, 4, dan 5). Struktur lanskap alami riparian sungai tersebut merupakan bentuk penggunaan lahan agroforestri yang 
umum ditemukan pada lanskap riparian (Arifin et al., 2009 dan Noviandi et al., 2016). Secara ekologi, fungsi struktur alami tersebut adalah mengatur aliran udara dan temperatur di sepanjang sungai, sebagai media aliran air, sebagai pengatur pergerakan air tanah, menyaring zat-zat kimia yang dapat mencemari sungai, dan sebagai habitat untuk bermacam-macam hewan dan tumbuhan baik terestrial maupun akuatik (Stevaux et al., 2013). Pacth-pacth dan koridor-koriodor alami tersebut memiliki ukuran-ukuran luas, kerapatan, bentuk, dan tepi yang besar dan beragam, sehingga dapat menjadi habitat inti (core) dan sumber makanan berbagai satwa dan juga manusia. Selain struktur agroforestri, pada lanskap riparian Sungai Ciliwung di Kota Bogor juga terdapat struktur buatan yang merupakan bentuk intervensi manusia terhadap lanskap. Struktur buatan tersebut adalah permukiman, perumahan, lahan kosong, kolam, dan jalan dengan ukuran luas, bentuk, kerapatan, dan tepi lanskap yang beragam. Berdasarkan nilai indeks ekologi lanskap, patch permukiman dan perumahan serta koridor jalan merupakan struktur buatan yang mulai mendominasi dan mengkonversi kawasan alami riparian sungai. Struktur buatan tersebut secara ekologi berfungsi sebagai habitat inti (core) dan sebagai media pergerakan material dan energi yang berhubungan dengan aktivitas manusia (Forman \& Godron, 1983).

\section{Analisis Dinamika Lanskap}

Dinamika lanskap riaprian Sungai Ciliwung di Kota Bogor dalam penelitian ini hanya dianalisis secara spasial. Tapak penelitian dibagi menjadi tiga bagian, yaitu atas, tengah, dan bawah. Hal tersebut dilakukan untuk memudahkan analisis dengan melihat perubahanperubahan penggunaan lahan dan fungsinya. Hasil penelitian menunjukkan bahwa, patch-patch dan koridorkoridor penggunaan lahan yang teridentifikasi mempunyai konfigurasi lanskap yang berbeda pada setiap bagiannya. Berdasarkan nilai CA, pada bagian atas, struktur ekologi lanskap lebih didominasi oleh struktur buatan (permukimam, perumahan, lahan kosong, kolam, dan jalan) dengan nilai 34,65 ha atau $56,54 \%$, sedangkan struktur alaminya (anak sungai, talun, kebun campuran, dan pekarangan) yang hanya 26,64 ha atau 43,46 \% (Tabel 2 dan Gambar 3). Berbeda dengan bagian atas, struktur ekologi lanskap pada bagian tengah masih sedikit didominasi struktur agroforestri dengan nilai CA sebesar 17,59 ha atau $55,23 \%$, sedangkan struktur buatannya sebesar 14,26 ha atau 44,77\% (Tabel 2 dan Gambar 4). Bagian bawah memiliki karakter yang mirip dengan bagian atas, di mana struktur buatan lebih mendominasi lanskap riparian sungai yang mencapai 33,78 ha atau $60,50 \%$, dibanding dengan struktur alami yang hanya 22,05 ha atau 39,50\% (Tabel 2 dan Gambar 5). Data tersebut menunjukkan bahwa, lanskap riparian Sungai Ciliwung di Kota Bogor sudah terokupasi oleh struktur buatan (lahan terbangun), sebagai bentuk intervensi manusia terhadap lanskap untuk memenuhi kebutuhan hidupnya (Arifin et al., 2009). Sedikit berbeda pada bagian tengah, yang masih sedikit didomonasi lanskap agroforestri (alami), karena pada segmen ini terdapat tempat khusus yang ditetapkan sebagai kawasan konservasi, yaitu Kebun Raya Bogor. Dengan ditetapkannya suatu daerah menjadi kawasan kebun raya, maka kondisi vegetasi alami riparian sungainya masih akan tetap terjaga (Purnomo et al., 2015).

Dinamika spasial yang cukup unik dari lanskap riparian Sungai Ciliwung di Kota Bogor dapat dilihat berdasarkan nilai NP pada setiap bagian. Pada bagian atas, nilai NP terbanyak adalah jenis patch pekarangan dengan 546 patches, diikuti patch permukiman dan perumahan dengan jumlah masing-masing sebanyak 171 dan 102 patches. Pada segmen tengah, jumlah patch pekarangan juga terbanyak, yaitu berjumlah 130 patches, diikuti jenis patch permukiman ditempat kedua dengan jumlah 84 patches. Sedangkan jumlah patch terbanyak pada segmen bawah adalah jenis pekarangan dengan 788 patches, diikuti patch permukiman dan perumahan dengan jumlah masing-masing sebanyak 212 dan 134 patches (Tabel 3). Data tersebut menunjukkan bahwa, semakin banyak jumlah patch (NP) jenis permukiman dan perumahan, maka semakin banyak pula jumlah patch pekarangan pada suatu lanskap. Hal tersebut dikarenakan permukiman sangat erat kaitannya dengan lingkungan sekitarnya, seperti bangunan, jalan dan pekarangan yang menjadi salah satu sumber penghidupan penduduk. Luas rata-rata pekarangan per rumah tangga di riparian Sungai Ciliwung di Kota Bogor relatif sempit, hal ini disebabkan oleh fragmentasi lahan (Arifin, 1998).

Dinamika pada suatu lanskap menunjukkan bahwa lanskap secara umum tidak permanen, melainkan mengalami perubahan-perubahan dalam hal kualitas, konfigurasi, ukuran, bentuk, fungsi, dan lain-lain. Pemahaman terhadap dinamika lanskap memberikan implikasi besar terhadap pengelolaan dan perencanaan lanskap. Pengaruh dinamika lanskap ini sangat penting dalam pengendalian proses ekosistem (Arifin et al., 2009).

\section{SIMPULAN}

Penggunaan lahan eksisting pada riparian Sungai Ciliwung di Kota Bogor sudah didominasi oleh penggunaan lahan terbangun, seperti permukiman dan 
perumahan. Lahan terbangun tersebut telah mengambil alih lahan agroforestri riparian sungai, seperti talun, kebun campuran dan pekarangan. Dominansi patch permukiman mengindikasikan adanya intervensi aktivitas manusia yang tinggi pada lanskap riparian. Patch jenis pekarangan adalah struktur ekologi lanskap yang paling terfragmentasi pada riparian Sungai Ciliwung di Kota Bogor. Hadirnya patch permukiman dan perumahan telah memecah-mecah patch pekarangan yang merupakan salah satu struktur lanskap agroforestri riparian sungai menjadi berukuran kecil dan menyebar.

Struktur ekologi lanskap agroforestri, pada riparian Sungai Ciliwung di Kota Bogor memiliki ukuran luas, kerapatan, bentuk, dan tepi lanskap yang beragam, sehingga dapat menjadi habitat inti (core) dan sumber makanan berbagai satwa. Sementara struktur buatan (permukiman, perumahan, lahan kosong, kolam, dan jalan) yang mulai mendominasi kawasan riparian sungai dapat berfungsi sebagai habitat inti (core) dan sebagai media pergerakan material dan energi yang berhubungan dengan aktivitas manusia.

Lanskap riparian Sungai Ciliwung pada daerah pinggiran Kota Bogor (segmen atas dan bawah) sudah terokupasi oleh struktur buatan (lahan terbangun). Namun dengan adanya Kebun Raya Bogor sebagai kawasan konservasi, maka kondisi vegetasi alami riparian segmen tengah masih cukup terjaga. Dinamika spasial lanskap lain dari riparian Sungai Ciliwung di Kota Bogor adalah semakin banyak jumlah patch (NP) permukiman dan perumahan pada suatu lanskap, maka semakin banyak pula jumlah patch pekarangan pada lanskap tersebut.

\section{DAFTAR PUSTAKA}

Adi, B.T.S., Indrawan, A., Prasetyo, L.B. 2012. Analisis

Lanskap Ekologi untuk Mengukur Fragmentasi Penggunaan Lahan, Wilayah Hulu Kabupaten Bogor, Jawa Barat. https://jlskindonesia.wordpress.com (diakses 30 Mei 2017).

Arifin, H.S., Wulandari, C., Pramukanto, Q., Kaswanto, R.L. 2009. Analisis Lanskap Agroforestri: Konsep, Metode, dan Pengelolaan Agroforestri Skala Lanskap dengan Study Kasus Indonesia, Filipina, Laos, Thailand, dan Vietnam. IPB Press. Bogor, Indonesia.

Arifin, H.S. 1998. Effects of Urbanization on the Vegetation Structure of the Home Gardens in West Java Indonesia. Journal Japan J. Trop. Agric. Vol. 42 (2): 94-102.

[BPDAS] Balai Pengelolaan DAS Citarum-Ciliwung. 2013. Rencana Pengelolaan DAS Terpadu DAS Ciliwung. Bogor (ID): Departemen Kehutanan.

Congalton, R., Green, K. 1999. Assessing the Accuracy of Remote Sensed Data: Principles and Practices. Lewis Publishers. Washington DC.
Dindaroglu, T., Reis, M., Akay, A.E., Tonguc, F. 2015. Hydroecological approach for Determining the Width of Riparian Buffer Zones for Providing Soil Conservation and Water Quality. Int. J. Environ. Sci. Technol. 12:275-284.

Forman, R., Gordon, M. 1983. Lansdcape Ecology. John Wiley \& Son; New York.

Hartvigsen, M. 2014. Land Reform and Land Fragmentation in Central and Eastern Europe. Land Use Policy. 36: 330-341.

Khoiriah, I.F., Farda, N.M. 2010. Perbandingan Akurasi Klasifikasi Penutup Lahan Hasil Penggabungan Citra ALOS AVNIR-2 dan ALOS PALSAR pada Polarisasi Berbeda dengan Transformasi Wavelet. http://lib.geo.ugm.ac.id/ojs/index.php/jbi/article/view File/11/11 (diakses 30 Mei 2017).

Leitao, A.B., Ahern, J. 2002. Applying Landscape Ecological Concepts and Metrics in Sustainable Landscape Planning. Landscape and Urban Planning 59: 65-93.

McGarigal, K., Marks, B.J. 1995. FRAGSTATS. Spatial Pattern Analysis Program for Quantifying Landscape Structure. Version 2.0. Forest Science Department. Oregon State University.

Noviandi, T.U.Z., Arifin, H.S., Kaswanto. 2016. Manajemen Lanskap Riparian Sebagai Strategi Pengendalian Ruang Terbuka Biru pada Sungai Ciliwung [Seminar Hasil Tesis]. Institut Pertanian Bogor. Bogor.

Purnomo, D.W., Helmanto, H., Yudaputra, A. 2015. Peran Kebun Raya Indonesia dalam Upaya Konservasi Tumbuhan dan Penurunan Emisi Karbon. Pros Sem Nas Masy Biodiv Indon. 1: 66-70.

Republik Indonesia. 1990. Keputusan Presiden Nomor 32 Tahun 1990 tentang Pengelolaan Kawasan Lindung. Jakarta.

Republik Indonesia. 2011. Peraturan Presiden Nomor 93 Tahun 2011 tentang Kebun Raya. Jakarta.

Stevaux, J.C., Corradini, F.A., Aquino, S. 2012. Connectivity Processes and Riparian Vegetation of the Upper Paraná River, Brazil. J South American Earth Sciences. 46:113-121.

Susetyo, B., Widiatmaka, Arifin, H.S., Machfud, Nurhayati. 2014. Analisis Spasial Kemampuan dan Kesesuaian Lahan untuk Mendukung Model Perumusan Kebijakan Manajemen Lanskap di Sempadan Ciliwung, Kota Bogor. Majalah Ilmiah Globë. 16: 51-58.

York, A.M., Shrestha, M., Boone, C.G., Zhang, S., Harrington, J.A., Prebyl, T.J., Swann, A., Agar, M., Antolin, M.F., Nolen, B., Wright, J.B., Skaggs, R. 2011. Land Fragmentation Under Rapid Urbanization: A cross-site analysis of Southwestern cities. Urban Ecosyst 14: 429-455. 